\title{
SISTEM DINAMIS KETERSEDIAAN DAGING AYAM RAS PEDAGING (BROILER) DI PROVINSI BALI
}

\author{
I Putu Surya Atmaja, I Ketut Satriawan*, I Wayan Gede Sedana Yoga \\ PS Teknologi Industri Pertanian, Fakultas Teknologi Pertanian, Universitas Udayana, Kampus Bukit \\ Jimbaran, Badung, Kode pos : 80361; Telp/Fax : (0361) 701801.
}

Diterima 15 Januari 2018 / Disetujui 4 Februari 2019

\begin{abstract}
The demand of broilers meats in Bali Province are very high and more dominated from hotels, restaurants, cafes and industrial. The aims of this research are to establish the factors those influenced the availability broiler meat, to arrange dynamic system modeling broiler meat availability, calculate the availability policy for fulfilling the need of animal protein, to arrange alternative recommendation of scenario policy for fulfilling the demand of broiler meat in Bali Province. Simulation are conducted over a period of 10 years, starting from 2012 until 2021. The factors those influenced the availability broiler meat in Bali Province are broiler meat production and broiler meat requirements. The simulation result showed that the production of broilers meat in Bali Province did not afforded to fulfil the demands of broilers since 2012. The avaibilty of broilers in Bali Province mostly appointed the reduction from the bigining to the end of the simulation year. According to the simulation result several scenarios, the policy which was very effective and possible to be developed for fulfilling the demand of broilers meat is by adding the weight of broilers during the livestock and also by adding more chicken. Key words: system dynamics, availability, broiler meat, simulations
\end{abstract}

*Korespondensi Penulis:

Email : satriawan@unud.ac.id 


\section{PENDAHULUAN}

Peningkatan jumlah penduduk dari tahun ke tahun di Provinsi Bali menyebabkan peningkatan kebutuhan pangan. Pemenuhan kebutuhan pangan tersebut tidak hanya sebatas pada pemenuhan kebutuhan pangan pokok seperti karbohidrat, akan tetapi juga pemenuhan komponen pangan lain seperti protein. Pemenuhan kebutuhan protein masyarakat Provinsi Bali dapat dipenuhi dengan meningkatkan konsumsi protein nabati maupun protein hewani. Protein hewani tersebut dapat dipenuhi salah satunya dari konsumsi unggas yang termasuk dalam sub sektor peternakan. Ayam broiler merupakan salah satu alternatif yang dipilih dalam upaya pemenuhan kebutuhan protein hewani (Rasyaf, 2006). Kebutuhan daging ayam ras pedaging di Provinsi Bali sangat tinggi dan melebihi kemampuan produksi peternak di Provinsi Bali. Kebutuhan daging ayam ras pedaging akan meningkat terutama pada saat menjelang hari raya besar keagamaan seperti hari raya Idul Fitri, Natal, Imlek.

Berdasarkan data Direktorat Jendral Peternakan (2016) populasi ayam ras pedaging di Provinsi Bali tahun 2012 - 2016 mengalami peningkatan tiap tahun nya, pada tahun 2012 populasi ayam ras pedaging di Provinsi Bali sebanyak 5.872.311 ekor, meningkat menjadi 9.575.037 ekor pada tahun 2016. Tingkat produksi daging ayam ras (broiler) di Provinsi Bali tahun 2012 2016 mengalami peningkatan 26.634 ton pada tahun 2012 dan 88.789 ton pada tahun 2016. Peningkatan produksi daging ayam ras pedaging di Provinsi Bali disertai juga dengan peningkatan kebutuhan daging ayam ras pedaging. Untuk mendapatkan kestabilan antara kebutuhan dan produksi daging ayam ras pedaging digunakan metode simulasi.

Simulasi merupakan suatu metode untuk mempelajari macam-macam model sistem di dunia nyata secara luas dengan evaluasi numerik menggunakan software yang didesain untuk meniru operasi atau karakteristik sistem tertentu (Kelton, 2010). Simulasi telah terbukti sebagai alat evaluasi performansi yang efektif dan alat pemodelan untuk sistem stokastik di dunia nyata yang sangat kompleks. Salah satu pendekatan simulasi yang akhir-akhir ini banyak dipakai adalah dengan sistem dinamis. Penerapan simulasi sistem dinamis pada supply chain produk pertanian digunakan untuk memprediksikan ketersediaan beras di Jawa Timur pada tahun 2013-2020 dan menganalisis kesiapan Jawa Timur untuk mencapai surplus $60 \%$ beras nasional. Dari hasil simulasi yang telah dilakukan, diperoleh ketersediaan beras di Jawa Timur pada tahun 2014 sebesar 3.944.377,7 ton. Dengan ketersediaan tersebut, maka target Jawa Timur untuk menyumbang $60 \%$ dari surplus 10 juta ton beras nasional 2014 belum bisa tercapai (Garside dan Asjari, 2015).

Penelitian Harmini dkk., (2011) menggunakan simulasi sistem dinamis untuk mengidentifikasi secara menyeluruh ketersediaan daging sapi nasional, menyusun model dinamis dan memproyeksikan ketersediaan daging sapi nasional di masa mendatang. Hasan et al., (2015) menggunakan kerangka sistem dinamis dalam analisis produksi kedelai dan permintaan untuk mengembangkan kebijakan strategis swasembada pangan, menunjukkan bahwa produksi kedelai bisa diproduksi untuk memenuhi permintaan kebutuhan kedelai di Indonesia selama 20 tahun. (Satriawan, 1993) menggunakan simulasi sistem dinamis untuk melihat prospek swasembada pangan di Provinsi Bali. Dari hasil simulasi yang telah dilakukan lahan kering dan lahan sawah mengalami penyusutan dan berdampak pada produksi pangan, dari enam komoditi yang dikaji (jagung, kacang tanah, ubi kayu dan ubi jalar) rata-rata produksi setiap komoditi mengalami kenaikan tetapi kenaikannya lebih kecil dari 
laju penyusutan lahan dan pertumbuhan penduduk sehingga tingkat swasembada juga mengalami penurunan dari tahun ke tahun.

Krisdayanti et al., (2017) menggunakan simulasi sistem dinamis untuk menghitung ketersediaan kedelai dalam upaya pencapaian swasembada pangan di Provinsi Bali, hasil simulasi yang telah dilakukan secara riil setiap tahun kedelai mengalami penurunan produksi, luas areal tanam dan produktivitas sehingga untuk memenuhi kebutuhan kedelai di Provinsi Bali dilakukan dengan pendayagunaan lahan yaitu $15 \%$ pertahun dari luas areal tanam kedelai dan peningkatan produktivitas dengan upaya intensifikasi. Indayani et al., (2017) menggunakan simulasi sistem dinamis untuk menganalisis ketersediaan buah pisang di Provinsi Bali, dari hasil simulasi yang telah dilakukan menunjukan produksi pisang belum mampu memenuhi kebutuhan pisang sehingga harus dilakukan upaya peningkatan produktivitas rata-rata dan diimbangi dengan upaya pendayagunaan lahan atau perluasan areal tanam pisang.

Berdasarkan kemampuan simulasi dalam menirukan perilaku sistem yang dapat memprediksi kondisi mendatang maka penelitian lebih lanjut mengenai sistem dinamis ketersediaan daging ayam ras pedaging dilakukan di Provinsi Bali. Penelitian ini bertujuan untuk (1) menentukan faktor-faktor yang mempengaruhi ketersediaan daging ayam ras pedaging, (2) menyusun pemodelan dinamis sistem ketersediaan daging ayam ras pedaging, (3) membuat model dinamis ketersediaan daging ayam ras pedaging, dan (4) merumuskan alternatif rekomendasi kebijakan untuk memenuhi kebutuhan daging ayam ras pedaging di Provinsi Bali.

\section{METODE PENELITIAN}

\section{Waktu dan Lokasi Penelitian}

Penelitian sistem dinamis ketersediaan daging ayam ras pedaging, dilakukan di Provinsi Bali. Pengolahan data dilakukan di Laboratorium Teknik Industri, Fakultas Teknologi Pertanian, Universitas Udayana. Pemilihan lokasi dilakukan dengan mempertimbangkan bahwa Provinsi Bali sebagai salah satu destinasi pariwisata dan banyak didatangi wisatawan hingga tenaga kerja yang mempengaruhi tingkat konsumsi daging ayam ras pedaging. Selain itu daging ayam sebagai salah satu makanan pokok pemenuhan kebutuhan protein hewani sebagian besar masyarakat di Provinsi Bali. Penelitian ini dilakukan pada bulan Juni - Juli 2017.

\section{Tahapan Penelitian}

Penelitian ini dilakukan dengan beberapa tahapan sesuai dengan metodologi pengembangan model dinamis yaitu (1) identifikasi masalah dan tujuan, (2) konseptualisasi model, (3) penyusunan diagram sebab akibat, (4) formulasi model, verifikasi dan validasi model, (5) simulasi dengan skenario dan (6) penyusunan alternatif rekomendasi kebijakan Dengan melihat hasil dari 4 skenario yang telah dirancang dan dilakukan melalui diskusi bersama ahli dibidang sistem dinamis, kemudian dapat diambil kesimpulan untuk dapat menghasilkan rekomendasi skenario terhadap kebijakan yang akan dilakukan sesuai dengan tujuan simulasi

\section{HASIL DAN PEMBAHASAN}

\section{Gambaran Umum Daging Ayam Ras Pedaging di Provinsi Bali \\ Pemenuhan kebutuhan protein} memiliki arti penting dalam aspek pangan dan ekonomi masyarakat. Daging ayam ras pedaging dalam aspek pangan ditujukan untuk pemenuhan kebutuhan protein hewani. Populasi ayam ras pedaging di Provinsi Bali pada tahun 2016 sebanyak 9,059,264 ekor. Kebutuhan daging ayam ras pedaging di 
Provinsi Bali tiap tahun mengalami kenaikan seiring dengan pertumbuhan penduduk dan angka net migrasi di Provinsi Bali. Daging ayam ras pedaging juga digunakan utuk memenuhi kebutuhan hotel, restoran, cafe (HORECA), kebutuhan hari raya (idul fitri, idul adha, natal, imlek dan hari besar keagamaan umat Hindu), kebutuhan langsung dan kebutuhan industri olahan. Perkembangan produksi daging ayam ras pedaging di Provinsi Bali saat ini belum bisa memenuhi semua kebutuhan daging ayam ras pedaging.

\section{Rancangan Model Ketersediaan Daging Ayam Ras Pedaging di Provinsi Bali}

\section{Deskripsi Sistem}

Daging ayam ras pedaging (Broiler) di Provinsi Bali menjadi salah satu kebutuhan utama dalam pemenuhan asupan protein hewani baik dari konsumsi sehari hari maupun konsumsi hari raya keagamaan, kebutuhan pangan protein hewani merupakan permasalahan ketersediaan yang kompleks dengan melibatkan beberapa variabel yang saling berkaitan satu sama lain. Sehingga ketersediaan daging ayam ras pedaging dibutuhkan pemantauan setiap tahunnya dengan tujuan untuk mengetahui faktor yang mempengaruhi ketersediaan daging ayam ras pedaging di Provinsi Bali. Sistem ketersediaan daging ayam ras pedaging dibuat model simulasi yang sesuai dengan model permasalahan di lapangan sebagai arah kebijakan dalam pengambilan keputusan. Model sistem dinamis yang dikembangkan dibatasi pada hal-hal yang berkaitan dengan produksi serta kebutuhan daging ayam ras pedaging di Provinsi Bali. Ketersediaan daging ayam ras pedaging dibagi menjadi dua submodel (subsistem) yaitu submodel produksi dan submodel kebutuhan untuk mempermudah dalam pemodelan. Pemodelan simulasi ketersediaan daging ayam ras pedaging di Provinsi Bali dituangkan ke dalam bentuk matematis dengan menggunakan software Vensim PLE.

\section{Konseptualisasi Model}

Sistem dinamis ketersediaan daging ayam ras pedaging dibuat dalam bentuk Causal loop diagram (CLD) dan stok flow diagram (SFD) untuk mempermudah melihat hubungan antar variabel. CLD akan menggambarkan kejadian sebab akibat dari variabel-variabel ke dalam gambar yang ditampilkan berupa panah-panah yang saling terkait. SFD menggambarkan hubungan variabel dengan menuliskan formulasi di dalam variabel berdasarkan hubungan variabel satu dengan yang lain. Model konseptual interaksi antara submodel utama dengan model lainnya disajikan pada Gambar 1 .

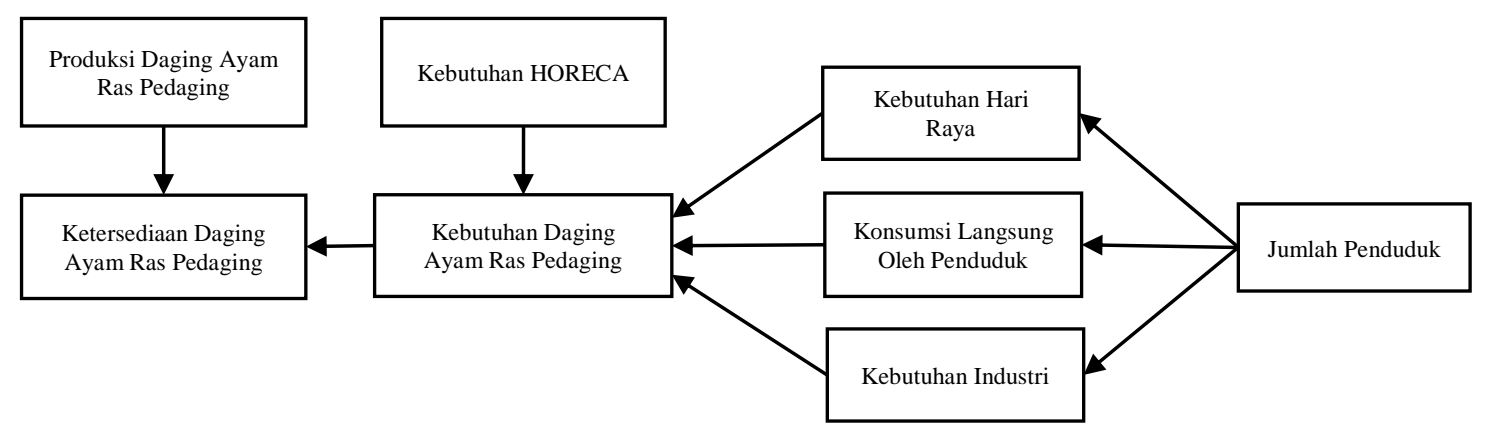

Gambar 1. Model Konseptual Ketersediaan Daging Ayam Ras Pedaging

Model konseptual ketersediaan daging ayam ras pedaging menggambarkan hubungan yang saling mempengaruhi yaitu ketersediaan daging ayam ras pedaging dipengaruhi oleh produksi dan kebutuhan daging ayam ras pedaging. Kebutuhan daging 
ayam ras pedaging dipengaruhi oleh kebutuhan horeca (hotel, restoran, cafe), kebutuhan hari raya, konsumsi langsung oleh penduduk dan kebutuhan industri yang terdiri dari industri sosis ayam, industri bakso ayam, industri ayam goreng yang dipengaruhi oleh jumlah penduduk di Provinsi Bali. Model yang dibuat merupakan gambaran dari sistem nyata yang memiliki dua submodel yaitu submodel produksi daging ayam ras pedaging dan submodel kebutuhan daging ayam ras pedaging.

\section{Formulasi Model}

Formulasi model ini menghubungkan variabel-variabel yang telah diidentifikasi dalam model konseptual dengan menggunakan bahasa simbolik dari software Vensim. Dalam penyusunan Stock and flow diagram ketersediaan daging ayam ras pedaging di Provinsi Bali memiliki beberapa submodel yang akan mewakili submodel produksi, submodel kebutuhan. Formulasi model dinamis dalam software vensim ditunjukkan pada Gambar 2.

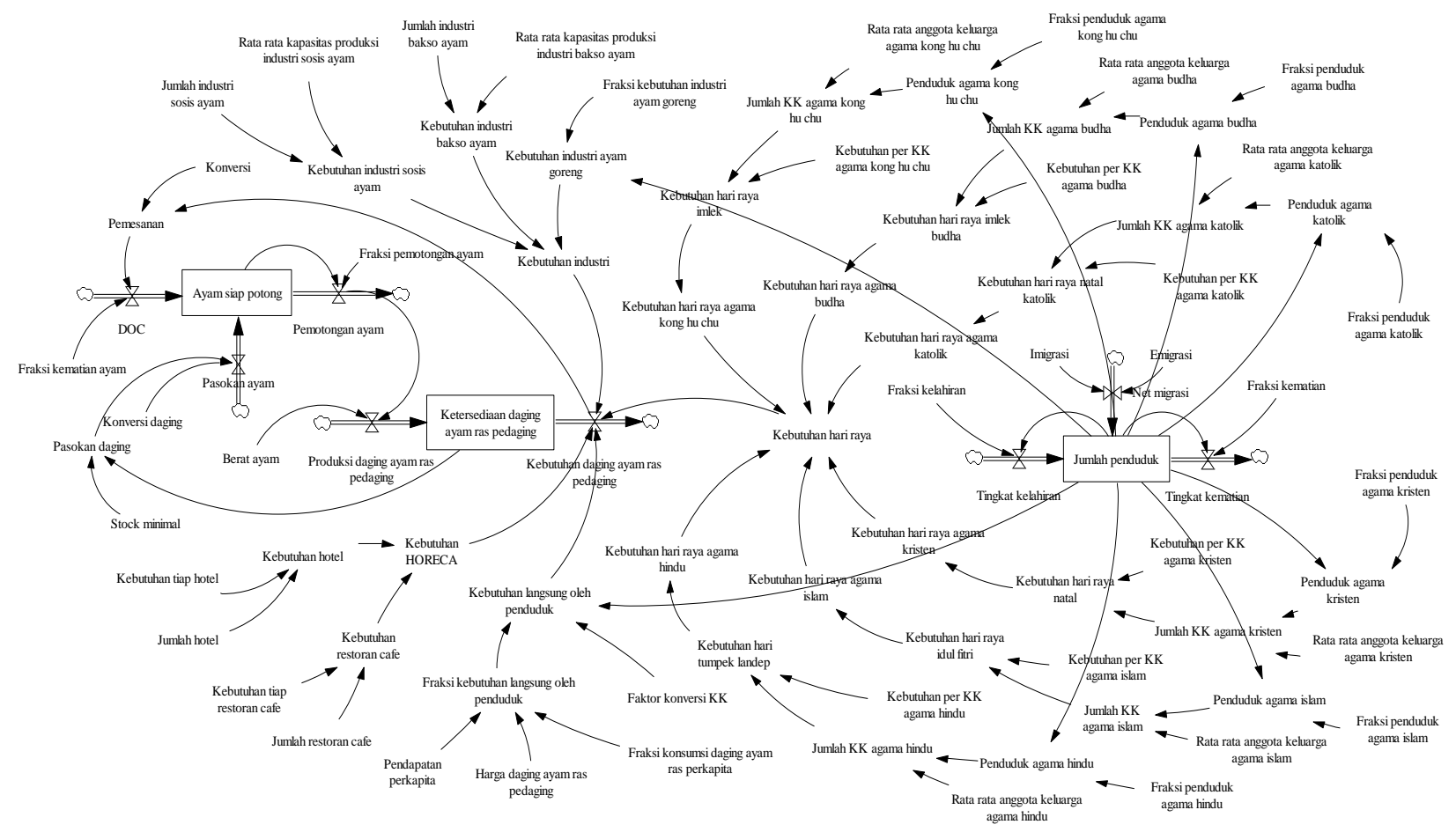

Gambar 2. Formulasi Model Sistem Dinamis Ketersediaan Daging Ayam Ras Pedaging.

\section{Verifikasi dan Validasi Model}

Verifikasi model merupakan tahapan yang dilakukan untuk memastikan model yang telah dibuat apakah sudah sesuai dengan konsep secara tepat atau tidak antara model dengan kondisi nyata. Vensim (Ventana Simulation) merupakan software yang digunakan dalam proses verifikasi, ketika model tidak menyatakan pesan error maka model tersebut telah verified (bebas error). Verifikasi ketersediaan daging ayam ras pedaging di Provinsi Bali dapat dilihat pada
Gambar 3 yang menyatakan "Unit are ok" artinya model sudah terverifikasi.

Validasi akan dilakukan menggunakan uji statistik t-paired test Model ketersedian daging ayam ras pedaging di Provinsi Bali sudah dinyatakan valid. Tabel 1 menyatakan Hasil validasi data aktual dengan data simulasi produksi daging ayam ras pedaging menghasilkan $P$ value 0,153 dan jumlah penduduk 0,51 yang artinya $P$ value lebih besar dari $0,051 P$ value $\geq \alpha$ maka $\mathrm{H}_{0}$ diterima, artinya tidak ada perbedaan yang 
signifikan antara output nyata dan output simulasi. Model ketersediaan daging ayam ras pedaging di Provinsi Bali sudah dinyatakan valid.

Tabel 1. Hasil Validasi Menggunakan t-paired test.

\begin{tabular}{lllllll}
\hline Variabel & Tahun & Hasil aktual & $\begin{array}{l}\text { Data } \\
\text { simulasi }\end{array}$ & P value & $\alpha$ & Kesimpulan \\
\hline Produksi daging & 2012 & 26.634 & 11.157 & 0,381 & 0,05 & $\mathrm{H}_{0}$ diterima \\
ayam ras pedaging & 2013 & 31.619 & 66.589 & & & \\
(ton) & 2014 & 53.853 & 39.241 & & & \\
& 2015 & 62.721 & 39.803 & & & \\
\hline Jumlah penduduk & 2016 & 88.789 & 40.371 & & & \\
& 2012 & 4.007 .200 & 4.007 .200 & 0,051 & 0,05 & $\mathrm{H}_{0}$ diterima \\
& 2013 & 4.056 .300 & 4.081 .960 & & & \\
& 2014 & 4.104 .900 & 4.157 .540 & & & \\
& 2015 & 4.152 .800 & 4.233 .970 & & & \\
& 2016 & 4.200 .100 & 4.311 .250 & & & \\
\hline
\end{tabular}

\section{Hasil Simulasi Berbagai Skenario}

Simulasi model dilakukan untuk mendapatkan hasil serta perilaku sistem selama periode simulasi 2012-2021. Dalam model dinamis ini dicobakan beberapa kebijakan melalui simulasi skenario untuk mengetahui ketersediaan daging ayam ras di Provinsi Bali. Pada model dinamis, skenario dilakukan dengan cara mengubah nilai variabel yang berkaitan sebagai implementasi dari suatu kebijakan yang ingin dilakukan.

\section{Skenario kondisi existing (skenario 1)}

Skenario kondisi saat ini merupakan skenario yang dianggap tetap tanpa adanya perubahan kebijakan. Skenario ini adalah kebijakan pada saat sekarang yang akan digunakan pada tahun 2012-2021. Dari skenario kondisi saat ini dapat dilihat dalam kurun waktu 5 tahun yang diasumsikan beberapa komponen tidak mengalami perubahan akan berjalan alami seperti kondisi saat ini. Pada skenario ini rata-rata konsumsi per kapita daging ayam ras pedaging sebanyak 0,0034 fraction/KK (Setjen Pertanian, 2016). Kebutuhan daging ayam ras pedaging di Provinsi Bali tidak dapat terpenuhi. Kekurangan daging ayam ras pedaging sudah terjadi pada tahun 2012 dengan kekurangan sebesar 23.499 ton dan terpenuhi pada tahun kedua hingga tahun 2021. Hal ini disebabkan karena terdapat pasokan ayam ras pedaging yang masuk jika ketersediaan daging mengalami defisit dan pemesanan DOC yang mengikuti kebutuhan maka semakin tinggi kebutuhan daging ayam ras pedaging maka semakin tinggi pemesanan sehingga produksi daging ayam ras pedaging juga meningkat seiring meningkatnya kebutuhan.

Kebutuhan daging ayam disetiap industri terus mengalami peningkatan sehingga produksi daging ayam ras pedaging harus meningkat sehingga mampu memenuhi kebutuhan daging ayam ras secara keseluruhan dari tahun 2012-2021. Peningkatan kebutuhan daging ayam ras pedaging terjadi karena mengalami peningkatan jumlah penduduk di Provinsi Bali. Banyaknya jumlah penduduk di Provinsi Bali mengakibatkan kebutuhan terhadap daging ayam ras pedaging menjadi tinggi. Hasil simulasi kebutuhan daging ayam ras pedaging tanpa perubahan kebijakan disajikan pada Tabel 2. 
Tabel 2. Hasil Simulasi Skenario Tanpa Perubahan Kebijakan.

\begin{tabular}{lllll}
\hline Tahun & $\begin{array}{l}\text { Jumlah } \\
\text { Penduduk Bali }\end{array}$ & $\begin{array}{l}\text { Produksi Daging } \\
\text { Ayam Ras Pedaging } \\
\text { (Ton) }\end{array}$ & $\begin{array}{l}\text { Kebutuhan Daging } \\
\text { Ayam Ras Pedaging } \\
\text { (Ton) }\end{array}$ & $\begin{array}{l}\text { Ketersediaan } \\
\text { Daging Ayam Ras } \\
\text { Pedaging (Ton) }\end{array}$ \\
\hline 2012 & $4,007,200$ & 11.157 & 34.656 & -23.499 \\
2013 & $4,081,960$ & 66.589 & 35.154 & 31.109 \\
2014 & $4,157,540$ & 39.241 & 35.658 & 3.583 \\
2015 & $4,233,970$ & 39.803 & 36.167 & 3.636 \\
2016 & $4,311,250$ & 40.371 & 36.681 & 3.698 \\
2017 & $4,389,390$ & 40.945 & 37.202 & 3.744 \\
2018 & $4,468,400$ & 41.526 & 37.728 & 3.798 \\
2019 & $4,548,290$ & 42.113 & 38.260 & 3.854 \\
2020 & $4,629,070$ & 42.707 & 38.798 & 3.910 \\
2021 & $4,710,740$ & 43.308 & 39.342 & 3.966 \\
\hline
\end{tabular}

2. Skenario Pengaruh Peningkatan Produksi (skenario 2)

Skenario kedua adalah skenario peningkatan produksi daging ayam ras pedaging, dengan mengasumsikan terjadi peningkatan produksi dengan melakukan penambahan berat ayam ras pedaging. Berat ayam yang akan dipotong di asumsikan meningkat dari $1,66 \mathrm{~kg}$ menjadi $2,1 \mathrm{~kg}$. Peningkatan berat ayam yang akan dipanen dilakukan dengan menambahkan vitamin, makanan, asupan, sesuai standar asupan gizi dan juga penambahan umur panen yang semula panen dilakukan pada 4 minggu menjadi 5 minggu (Manurung, 2011).

Berdasarkan penelitian (Manurung, 2011) Dengan pemberian pakan standar kebutuhan gizi ayam, yaitu perlakuan pakan diberikan pagi $50 \%$ dan sore $50 \%$ dan umur panen 5 minggu menghasilkan bobot badan akhir 2,102 kg/ekor dengan angka mortalitas $0 \%$. Hasil simulasi peningkatan berat ayam ras pedaging pada produksi daging ayam ras pedaging disajikan pada Tabel 3.

Tabel 3. Hasil Simulasi Skenario Pengaruh Peningkatan Produksi.

\begin{tabular}{lllll}
\hline Tahun & $\begin{array}{l}\text { Jumlah } \\
\text { Penduduk } \\
\text { Bali }\end{array}$ & $\begin{array}{l}\text { Produksi Daging } \\
\text { Ayam Ras Pedaging } \\
\text { (Ton)** }\end{array}$ & $\begin{array}{l}\text { Kebutuhan Daging } \\
\text { Ayam Ras Pedaging } \\
\text { (Ton) }\end{array}$ & $\begin{array}{l}\text { Ketersediaan Daging } \\
\text { Ayam Ras Pedaging } \\
\text { (Ton)** }\end{array}$ \\
\hline 2012 & $4,007,200$ & 12.332 & 34.656 & -22.324 \\
2013 & $4,081,960$ & 72.087 & 35.154 & 36.903 \\
2014 & $4,157,540$ & 43.371 & 35.658 & 7.714 \\
2015 & $4,233,970$ & 43.992 & 36.167 & 7.826 \\
2016 & $4,311,250$ & 44.620 & 36.681 & 7.939 \\
2017 & $4,389,390$ & 45.255 & 37.202 & 8.054 \\
2018 & $4,468,400$ & 45.898 & 37.728 & 8.170 \\
2019 & $4,548,290$ & 46.547 & 38.260 & 8.287 \\
2020 & $4,629,070$ & 47.203 & 38.798 & 8.405 \\
2021 & $4,710,740$ & 47.867 & 39.342 & 8.525 \\
\hline
\end{tabular}

Keterangan $* *$ : nilai produksi dan ketersediaan ayam ras pedaging tiap tahun lebih tinggi dari hasil simulasi skenario 1. 
3. Skenario Pengaruh Peningkatan Kebutuhan (skenario 3)

Skenario ketiga yaitu pengaruh peningkatan kebutuhan, dimana model dirancang dengan mengasumsikan terjadinya perubahan pada kebutuhan daging ayam ras pedaging yang dipengaruhi oleh peningkatan kebutuhan langsung oleh penduduk, kebutuhan hari raya, kebutuhan HORECA dan kebutuhan industri olahan di Provinsi Bali. Peningkatan kebutuhan daging ayam ras pedaging dipengaruhi oleh pertumbuhan penduduk dan wisatawan yang datang ke Bali.

Pertumbuhan penduduk mempengaruhi peningkatan konsumsi langsung, kebutuhan hari raya dan kebutuhan industri. Jumlah penduduk diasumsikan meningkat dengan cara menekan tingkat kematian. Fraksi kematian diasumsikan mengalami penurunan yaitu dari 0,0034 fraction/year dengan angka kematian kasar 3,4 menjadi 0,0028 fraction/year dengan angka kematian kasar 2,8 berdasarkan data fraksi kematian Provinsi Bengkulu tahun 2012-2015 (diolah dari data Riskesdas 2007 dan BPS Provinsi Bengkulu, 2016). Penurunan fraksi kematian memungkinkan akan terjadi, mengingat bahwa angka fraksi kematian di Provinsi Bali dari tahun 2012 - 2016 mengalami penurunan setiap tahunnya (BPS Provinsi Bali 2016).

Jumlah wisatawan yang datang ke Bali mempengaruhi peningkatan kebutuhan pada HORECA. Rata-rata peningkatan pertumbuhan penduduk adalah $2 \%$ dan ratarata kunjungan wisatawan yang datang ke Bali adalah 12\% (BPS, 2016). Kebutuhan langsung, hari raya, HORECA dan industri olahan diasumsikan meningkat dengan cara menaikkan angka rata-rata kebutuhan daging daging ayam ras pedaging. Peningkatan kebutuhan disajikan pada Tabel 4.

Tabel 4. Peningkatan Kebutuhan Daging Ayam Ras Pedaging

\begin{tabular}{|c|c|c|c|}
\hline & $\begin{array}{l}\text { Persentase } \\
\text { Kenaikkan }\end{array}$ & $\begin{array}{l}\text { Kebutuhan } \\
\text { Awal }\end{array}$ & $\begin{array}{l}\text { Kebutuhan } \\
\text { Naik }\end{array}$ \\
\hline $\begin{array}{l}\text { Kebutuhan Langsung } \\
\text { Konsumsi per kapita }\end{array}$ & $2 \%$ & 0,003400 & 0,003468 \\
\hline $\begin{array}{l}\text { Kebutuhan HORECA } \\
\text { Rata-rata kebutuhan Hotel } \\
\text { Rata-rata kebutuhan RestoranCafe }\end{array}$ & $\begin{array}{l}12 \% \\
12 \%\end{array}$ & $\begin{array}{l}6,8404 \\
8,4305 \\
\end{array}$ & $\begin{array}{l}7,6612 \\
9,4421\end{array}$ \\
\hline $\begin{array}{l}\text { Kebutuhan Industri Olahan } \\
\text { Rata-rata kebutuhan sosis ayam } \\
\text { Rata-rata kebutuhan bakso ayam } \\
\text { Rata-rata kebutuhan ayam goreng }\end{array}$ & $\begin{array}{l}2 \% \\
2 \% \\
2 \% \\
\end{array}$ & $\begin{array}{l}50,0000 \\
48,0000 \\
0,0048 \\
\end{array}$ & $\begin{array}{l}51,0000 \\
48,9600 \\
0,004896 \\
\end{array}$ \\
\hline
\end{tabular}

Kenaikan kebutuhan daging ayam ras pedaging memungkinkan terjadi mengingat bahwa jumlah kunjungan wisatawan ke Provinsi Bali dan pertumbuhan penduduk mengalami peningkatan setiap tahunnya. Perubahan peningkatan kebutuhan berakibat pada produksi daging ayam ras pedaging tidak dapat memenuhi kebutuhan daging ayam ras pedaging. Hasil simulasi skenario pengaruh peningkatan kebutuhan disajikan pada Tabel 5. 
Tabel 5. Hasil Simulasi Peningkatan Kebutuhan Daging Ayam Ras Pedaging pada Skenario 3.

\begin{tabular}{lllll}
\hline Tahun & $\begin{array}{l}\text { Jumlah } \\
\text { Penduduk } \\
\text { Bali** }\end{array}$ & $\begin{array}{l}\text { Produksi Daging } \\
\text { Ayam Ras } \\
\text { Pedaging (Ton) }\end{array}$ & $\begin{array}{l}\text { Kebutuhan Daging } \\
\text { Ayam Ras } \\
\text { Pedaging (Ton)** }\end{array}$ & $\begin{array}{l}\text { Ketersediaan } \\
\text { Daging Ayam Ras } \\
\text { Pedaging (Ton)** }\end{array}$ \\
\hline 2012 & 4.007 .200 & 11.157 & 36.020 & -24.863 \\
2013 & 4.084 .520 & 69.732 & 36.544 & 33.187 \\
2014 & 4.162 .760 & 40.793 & 37.075 & 3.718 \\
2015 & 4.241 .910 & 41.385 & 37.612 & 3.773 \\
2016 & 4.321 .990 & 41.984 & 38.155 & 3.829 \\
2017 & 4.403 .020 & 42.591 & 38.704 & 3.886 \\
2018 & 4.485 .010 & 43.204 & 39.261 & 3.943 \\
2019 & 4.567 .950 & 43.825 & 39.823 & 4.001 \\
2020 & 4.651 .880 & 44.453 & 40.392 & 4.060 \\
2021 & 4.736 .790 & 45.088 & 40.968 & 4.120 \\
\hline
\end{tabular}

Keterangan **: nilai jumlah penduduk, kebutuhan daging ayam ras pedaging dan ketersediaan daging ayam ras pedaging tiap tahun lebih tinggi dari hasil simulasi skenario 1 .

Perubahan peningkatan kebutuhan mengakibatkan ketersediaan daging ayam ras pedaging tiap tahun lebih tinggi dari skenario 1 karena pemesanan DOC dipengaruhi oleh kebutuhan, maka semakin tinggi kebutuhan daging ayam ras pedaging semakin tinggi pemesanan DOC.

4. Skenario Peningkatan Produksi dan Kebutuhan (skenario 4)

Skenario keempat merupakan skenario dari penggabungan dari skenario 2 peningkatan produksi dan skenario 3 peningkatan kebutuhan. Peningkatan produksi dengan cara menaikkan berat berat ayam yang akan dipotong. Berat ayam yang akan dipotong diasumsikan meningkat sebesar dari 1,66 kg menjadi 2,1 kg. Peningkatan berat ayam yang akan dipanen dilakukan dengan menambahkan vitamin, makanan, asupan, sesuai standar asupan gizi dan juga penambahan umur panen yang semula panen dilakukan pada 4 minggu menjadi 5 minggu (Manurung, 2011). Dengan pemberian pakan standar kebutuhan gizi ayam, yaitu perlakuan pakan diberikan pagi $50 \%$ dan sore $50 \%$ dan umur panen 5 minggu menghasilkan bobot badan akhir $2,102 \mathrm{~kg}$ /ekor dengan angka mortalitas $0 \%$ (Manurung, 2011).

Peningkatan kebutuhan daging ayam ras pedaging dipengaruhi oleh pertumbuhan penduduk dan wisatawan yang datang ke Bali. Pertumbuhan penduduk mempengaruhi peningkatan konsumsi langsung, kebutuhan hari raya dan kebutuhan industri. Jumlah penduduk diasumsikan meningkat dengan cara menekan tingkat kematian. Fraksi kematian diasumsikan mengalami penurunan yaitu dari 0,0034 fraction/year menjadi 0,0028 fraction/year dengan angka. Jumlah wisatawan yang datang ke Bali mempengaruhi peningkatan kebutuhan pada HORECA. Rata-rata peningkatan pertumbuhan penduduk adalah $2 \%$ dan ratarata kunjungan wisatawan yang datang ke Bali adalah 12\% (BPS, 2016). Kebutuhan diasumsikan meningkat dengan cara menaikkan angka rata-rata kebutuhan daging ayam ras pedaging. Hasil simulasi skenario peningkatan produksi dan kebutuhan disajikan pada Tabel 6. 
Tabel 6. Hasil Simulasi Skenario Peningkatan Produksi dan Kebutuhan.

\begin{tabular}{lllll}
\hline Tahun & $\begin{array}{l}\text { Jumlah } \\
\text { Penduduk } \\
\text { Bali** }\end{array}$ & $\begin{array}{l}\text { Produksi Daging } \\
\text { Ayam Ras } \\
\text { Pedaging (Ton)** }\end{array}$ & $\begin{array}{l}\text { Kebutuhan Daging } \\
\text { Ayam Ras Pedaging } \\
\text { (Ton)** }\end{array}$ & $\begin{array}{l}\text { Ketersediaan Daging } \\
\text { Ayam Ras Pedaging } \\
\text { (Ton)** }\end{array}$ \\
\hline 2012 & 4.007 .200 & 43.552 & 36.067 & 7.545 \\
2013 & 4.084 .520 & 44.187 & 36.531 & 7.655 \\
2014 & 4.162 .760 & 44.828 & 37.062 & 7.767 \\
2015 & 4.241 .910 & 45.478 & 37.599 & 7.879 \\
2016 & 4.321 .990 & 46.195 & 38.141 & 7.992 \\
2017 & 4.403 .020 & 46.799 & 38.691 & 8.108 \\
2018 & 4.485 .010 & 47.472 & 39.247 & 8.225 \\
2019 & 4.567 .950 & 48.152 & 39.810 & 8.342 \\
2020 & 4.651 .880 & 48.841 & 40.379 & 8.462 \\
2021 & 4.736 .790 & 49.537 & 40.955 & 8.582 \\
\hline
\end{tabular}

Keterangan **: nilai jumlah penduduk Bali, produksi, kebutuhan dan ketersediaan daging ayam ras pedaging tiap tahun lebih tinggi dari hasil simulasi skenario 1 .

\section{Alternatif Rekomendasi Kebijakan}

Produksi daging ayam ras pedaging di Provinsi Bali belum terpenuhi pada tahun 2012 dan baru terpenuhi di tahun 2013 hingga 2021. Kebutuhan daging ayam ras pedaging dapat terpenuhi dengan adanya pasokan ayam dan penambahan berat panen ayam dari 1,66 $\mathrm{kg}$ menjadi $2,1 \mathrm{~kg}$, sehingga perlu dilakukan beberapa perbaikan. Alternatif rekomendasi kebijakan yang dapat disarankan pada ketersediaan daging ayam ras pedaging, yaitu Mengurangi pasokan ayam ras pedaging untuk memaksimalkan potensi peternak lokal, dan menaikkan berat ayam yang akan dipotong dari $1,66 \mathrm{~kg}$ menjadi $2,1 \mathrm{~kg}$. Peningkatan berat ayam yang akan di panen dilakukan dengan menambahkan vitamin, makanan, asupan, sesuai standar asupan gizi dan juga penambahan umur panen yang semula panen dilakukan pada 4 minggu menjadi 5 minggu (Manurung, 2011).

\section{KESIMPULAN DAN SARAN}

\section{Kesimpulan}

Berdasarkan penelitian yang telah dilakukan maka dapat disimpulkan beberapa hal sebagai berikut :
1. Faktor-faktor yang mempengaruhi ketersediaan daging ayam ras pedaging di Provinsi Bali yaitu DOC, populasi ayam ras siap panen, pemotongan ayam ras pedaging, produksi daging ayam ras pedaging, pertumbuhan penduduk, net migrasi, kebutuhan hari raya, industri sosis, bakso dan ayam goreng, kebutuhan HORECA.

2. Ketersediaan daging ayam ras pedaging di Provinsi Bali secara riil setiap tahun mengalami penurunan, seiring dengan pertumbuhan penduduk, kebutuhan langsung, kebutuhan upacara dan kebutuhan industri.

3. Model dinamis ketersediaan daging ayam ras pedaging yang telah disimulasikan menunjukkan defisit ketersediaan daging ayam ras pedaging pada tahun 2012 23.499 ton, dan terpenuhi pada tahun 2013 - 2021.

4. Alternatif rekomendasi kebijakan untuk memenuhi kebutuhan daging ayam ras pedaging di Provinsi Bali dengan pasokan ayam untuk mengimbangi kebutuhan daging ayam ras. Berdasarkan skenario pada model, dapat dilakukan dengan cara menaikkan berat ayam ras yang akan di potong dari 1,66 kg menjadi 2,1 kg. Maka 
ketersediaan ayam ras pedaging akan terpenuhi sampai tahun 2021.

\section{Saran}

Potensi daging ayam ras pedaging di Provinsi Bali tidak bisa mencukupi kebutuhan daging ayam ras pedaging dari tahun 2012 - 2021, sehingga penambahan bobot ayam siap panen tidak bisa dihindarkan. Perlu diadakannya penelitian lebih lanjut dalam upaya meningkatkan suplai DOC, dengan cara menerapkan program kemitraan pada peternak, dalam upaya meningkatkan produksi untuk memenuhi kebutuhan daging ayam ras pedaging di Provinsi Bali.

\section{DAFTAR PUSTAKA}

Badan Pusat Statistik Provinsi Bengkulu. $2016 . \quad$ https://bengkulu.bps.go.id. Diakses pada 19 Januari 2017.

Badan Pusat Statistik Provinsi Bali. 2016. Sosial dan kependudukan. www.bali.bps.go.id. Diakses pada 29 Januari 2017.

Direktorat Jenderal Peternakan. 2016. Sub Sektor Peternakan 2016. www.pertanian.go.id/ap_pages/mod/da tanak. Diakses pada 2 Februari 2017.

Garside, A. K. dan H. Y. Asjari. 2015. Simulasi Ketersediaan Beras di Jawa Timur. Jurnal Ilmiah Teknik Industri. 14(1):47-58.

Harmini, R. W. Asmrantaka, dan J. Atmakusuma. 2011. Model Dinamis Sistem Ketersediaan Daging Sapi Nasional. Jurnal Ekonomi Pembangunan. 12(1):128-146.

Hasan, N., E. Suryani, and R. Hendrawan. 2015. Analysis of Soybean Production and Demand to Develop Strategic Policy of Food Self Sufficiency: A System Dynamics Framework.
Procedia Computer Science. 7(2):605612.

Indayani, N. P., I. K. Satriawan, C. A. B. Sadyasmara. 2017. Sistem Dinamis Ketersediaan Buah Pisang di Provinsi Bali. Jurnal Rekayasa dan Manajemen Agroindustri. 5(2) : 77-87.

Irianto, J., A. Musadad, dan Y. Wiryawan.2009. Angka Kematian di Berbagai Provinsi di Indonesia (Data Riskesdas 2007). Jurnal Ekologi Kesehatan. 3(8): 1047-1056.

Kelton, W. D., R. P. Sadowski, and N. B. Swets, 2010. Simulation with Arena. McGraw Hill. New York.

Krisdayanti, N. K. L., I. K. Satriawan., I. W. G. S. Yoga., 2017. Sistem Dinamik Ketersediaan Kedelai dalam Rangka Swasembada Pangan di Provinsi Bali. Jurnal Rekayasa dan Manajemen Agroindustri. 5(3) : 45-56.

Manurung, E.J. 2011. Performa ayam broiler pada frekuensi dam waktu pemberian pakan yang berbeda. Skripsi. Bogor. Institut Pertanian Bogor.

Rasyaf, M. 2006. Beternak Ayam Pedaging. Penebar Swadaya, Jakarta.

Satriawan, I K. 1993. Prospek Swasembada Pangan di Provinsi Bali dengan Pemodelan Sistem Dinamis. Tesis S2. Tidak dipublikasi. Program Magister Teknik dan Manajemen Industri. Program Pascasarjana. Institut Teknologi Bandung. Bandung.

Sekretariat Jenderal Pertanian. 2016. Sub Sektor Peternakan 2016. http://epublikasi.setjen.pertanian.go.id/ arsip-outlook/70-outlookpeternakan/416-outlook-daging-ayam2016. Diakses pada 1 Maret 2017.

Udin, F., Marimin, Sukardi, A. Buono and H. Halid. 2014. A System Dynamics 
Simulation of Rice Agroindustry Development by Divestment Pattern for Increasing Rice Production and
Farmer Income. Journal of Information Engineering and Applications. 4(12):82-95.

Lampiran 1. Formulasi Matematis Submodel Produksi dan Kebutuhan Daging Ayam Ras Pedaging

\begin{tabular}{|c|c|c|c|c|}
\hline No. & $\begin{array}{l}\text { Variabel di causal } \\
\text { loop }\end{array}$ & $\begin{array}{l}\text { Model } \\
\text { Building }\end{array}$ & Formulasi & Unit \\
\hline 1. & $\begin{array}{l}\text { Produksi daging } \\
\text { ayam ras pedaging }\end{array}$ & Flow & $\begin{array}{l}\text { Produksi daging ayam ras pedaging }= \\
\text { Pemotongan ayam } * \text { Berat ayam }\end{array}$ & $\begin{array}{l}\text { Ton/ } \\
\text { year }\end{array}$ \\
\hline 2. & Pemotongan ayam & Flow & $\begin{array}{l}\text { Pemotongan ayam = Ayam siap potong } * \\
\text { Fraksi pemotongan ayam }\end{array}$ & $\begin{array}{l}\text { Ekor/ } \\
\text { year }\end{array}$ \\
\hline 3. & Ayam siap potong & Stock & DOC+Pasokan ayam-Pemotongan ayam & $\begin{array}{l}\text { Ekor/ } \\
\text { year }\end{array}$ \\
\hline 4. & DOC & Flow & Pemesanan*Fraksi kematian ayam & $\begin{array}{l}\text { Ekor/ } \\
\text { year }\end{array}$ \\
\hline 5. & Pemesanan & Variabel & $\begin{array}{l}\text { Kebutuhan daging ayam ras pedaging * } \\
\text { konversi }\end{array}$ & $\begin{array}{l}\text { Ekor/ } \\
\text { year }\end{array}$ \\
\hline 6. & Pasokan daging & Variabel & $\begin{array}{l}\text { IF THEN ELSE( Ketersediaan daging ayam } \\
\text { ras pedaging }<0 \text {, Stock minimal- } \\
\text { Ketersediaan daging ayam ras pedaging, } 0 \text { ) }\end{array}$ & $\begin{array}{l}\text { Ton/ } \\
\text { year }\end{array}$ \\
\hline 7. & Pasokan ayam & Variabel & Konversi daging*Pasokan daging & $\begin{array}{l}\text { Ekor/ } \\
\text { year }\end{array}$ \\
\hline 8. & $\begin{array}{l}\text { Kebutuhan daging } \\
\text { ayam ras pedaging }\end{array}$ & Flow & $\begin{array}{l}\text { Kebutuhan daging ayam ras pedaging = } \\
\text { Kebutuhan HORECA+Kebutuhan } \\
\text { industri+Kebutuhan langsung oleh } \\
\text { penduduk }\end{array}$ & $\begin{array}{l}\text { Ton/ } \\
\text { year }\end{array}$ \\
\hline 9. & $\begin{array}{l}\text { Kebutuhan } \\
\text { HORECA }\end{array}$ & Variabel & $\begin{array}{l}\text { Kebutuhan HORECA = Kebutuhan } \\
\text { hotel+Kebutuhan restoran café }\end{array}$ & $\begin{array}{l}\text { Ton/ } \\
\text { year }\end{array}$ \\
\hline 10. & Kebutuhan hotel & Variabel & $\begin{array}{l}\text { Kebutuhan hotel = Kebutuhan tiap } \\
\text { hotel*Jumlah hotel }\end{array}$ & $\begin{array}{l}\text { Ton/ } \\
\text { year }\end{array}$ \\
\hline 11. & $\begin{array}{l}\text { Kebutuhan restoran } \\
\text { cafe }\end{array}$ & Variabel & $\begin{array}{l}\text { Kebutuhan restoran cafe }=\text { Jumlah restoran } \\
\text { cafe*Kebutuhan tiap restoran cafe }\end{array}$ & $\begin{array}{l}\text { Ton/ } \\
\text { year }\end{array}$ \\
\hline 14. & $\begin{array}{l}\text { Jumlah restoran } \\
\text { cafe }\end{array}$ & Variabel & $\begin{array}{l}\text { Jumlah restoran cafe }=30 \% \text { dari jumlah } \\
\text { restoran cafe tahun } 2015\end{array}$ & $\begin{array}{l}\text { Restora } \\
\text { ncafe }\end{array}$ \\
\hline 13. & $\begin{array}{l}\text { Kebutuhan } \\
\text { langsung oleh } \\
\text { penduduk }\end{array}$ & Variabel & $\begin{array}{l}\text { Fraksi kebutuhan langsung oleh } \\
\text { penduduk*Jumlah penduduk*Faktor } \\
\text { konversi KK }\end{array}$ & $\begin{array}{l}\text { Ton/ } \\
\text { year }\end{array}$ \\
\hline 14. & $\begin{array}{l}\text { Fraksi kebutuhan } \\
\text { langsung oleh } \\
\text { penduduk }\end{array}$ & Variabel & $\begin{array}{l}\text { (Pendapatan perkapita*Fraksi konsumsi } \\
\text { daging ayam ras perkapita)/Harga daging } \\
\text { ayam ras pedaging }\end{array}$ & $\begin{array}{l}\text { Ton/ } \\
\text { KK/ } \\
\text { year }\end{array}$ \\
\hline 15. & Jumlah penduduk & Stock & $\begin{array}{l}\text { Jumlah penduduk = Jumlah penduduk }(\mathrm{t}-\mathrm{dt}) \\
+ \text { Tingkat kelahiran - Tingkat kematian }+ \\
\text { Net migrasi }\end{array}$ & Orang \\
\hline 16. & Tingkat kelahiran & Flow & $\begin{array}{l}\text { Tingkat kelahiran }= \\
\text { Jumlah penduduk*Fraksi kelahiran }\end{array}$ & $\begin{array}{l}\text { Orang/ } \\
\text { year }\end{array}$ \\
\hline 17. & Tingkat kematian & Flow & Tingkat kematian $=$ & Orang/ \\
\hline
\end{tabular}




\begin{tabular}{|c|c|c|c|c|}
\hline No. & $\begin{array}{l}\text { Variabel di causal } \\
\text { loop }\end{array}$ & $\begin{array}{l}\text { Model } \\
\text { Building }\end{array}$ & Formulasi & Unit \\
\hline & & & Jumlah penduduk*Fraksi kematian & year \\
\hline 18. & Net migrasi & Variabel & Net migrasi = Imigrasi-emigrasi & $\begin{array}{l}\text { Orang/ } \\
\text { year }\end{array}$ \\
\hline 19. & $\begin{array}{l}\text { Kebutuhan hari } \\
\text { raya }\end{array}$ & Variabel & $\begin{array}{l}\text { Kebutuhan hari raya = Kebutuhan hari raya } \\
\text { agama budha+Kebutuhan hari raya agama } \\
\text { hindu+Kebutuhan hari raya agama } \\
\text { islam+Kebutuhan hari raya agama } \\
\text { katolik+Kebutuhan hari raya agama kong hu } \\
\text { chu+Kebutuhan hari raya agama kristen }\end{array}$ & $\begin{array}{l}\text { Ton/ } \\
\text { year }\end{array}$ \\
\hline 20. & $\begin{array}{l}\text { Kebutuhan hari } \\
\text { tumpek landep dan } \\
\text { upacara agama } \\
\text { hindu }\end{array}$ & Variabel & $\begin{array}{l}\text { Kebutuhan hari raya galungan = Jumlah KK } \\
\text { agama Hindu*Kebutuhan per KK agama } \\
\text { hindu }\end{array}$ & $\begin{array}{l}\text { Ton/ } \\
\text { year }\end{array}$ \\
\hline 21. & $\begin{array}{l}\text { Jumlah KK agama } \\
\text { hindu }\end{array}$ & Variabel & $\begin{array}{l}\text { Jumlah KK agama hindu = Penduduk } \\
\text { agama hindu/Rata rata anggota keluarga } \\
\text { agama hindu }\end{array}$ & $\begin{array}{l}\mathrm{KK} / \\
\text { year }\end{array}$ \\
\hline 22. & $\begin{array}{l}\text { Penduduk agama } \\
\text { hindu }\end{array}$ & Variabel & $\begin{array}{l}\text { Penduduk agama hindu }=\text { Fraksi penduduk } \\
\text { agama hindu*Jumlah penduduk }\end{array}$ & $\begin{array}{l}\text { Orang/ } \\
\text { year }\end{array}$ \\
\hline 23. & $\begin{array}{l}\text { Kebutuhan hari } \\
\text { raya idul fitri }\end{array}$ & Variabel & $\begin{array}{l}\text { Kebutuhan hari raya idul fitri = Jumlah KK } \\
\text { agama islam*Kebutuhan per KK agama } \\
\text { islam }\end{array}$ & $\begin{array}{l}\text { Ton/ } \\
\text { year }\end{array}$ \\
\hline 24. & $\begin{array}{l}\text { Jumlah KK agama } \\
\text { islam }\end{array}$ & Variabel & $\begin{array}{l}\text { Jumlah KK agama islam = Penduduk agama } \\
\text { islam/Rata rata anggota keluarga agama } \\
\text { islam }\end{array}$ & $\begin{array}{l}\text { KK/ } \\
\text { year }\end{array}$ \\
\hline 25. & $\begin{array}{l}\text { Penduduk agama } \\
\text { islam }\end{array}$ & Variabel & $\begin{array}{l}\text { Penduduk agama islam = Fraksi penduduk } \\
\text { agama islam*Jumlah penduduk }\end{array}$ & $\begin{array}{l}\text { Orang/ } \\
\text { year }\end{array}$ \\
\hline 26. & $\begin{array}{l}\text { Kebutuhan hari } \\
\text { raya natal }\end{array}$ & Variabel & $\begin{array}{l}\text { Kebutuhan hari raya natal = Jumlah KK } \\
\text { agama kristen*Kebutuhan per KK agama } \\
\text { kristen }\end{array}$ & $\begin{array}{l}\text { Ton/ } \\
\text { year }\end{array}$ \\
\hline 27. & $\begin{array}{l}\text { Jumlah KK agama } \\
\text { kristen }\end{array}$ & Variabel & $\begin{array}{l}\text { Jumlah KK agama kristen = Penduduk } \\
\text { agama kristen/Rata rata anggota keluarga } \\
\text { agama kristen }\end{array}$ & $\begin{array}{l}\mathrm{KK} / \\
\text { year }\end{array}$ \\
\hline 28. & $\begin{array}{l}\text { Penduduk agama } \\
\text { kristen }\end{array}$ & Variabel & $\begin{array}{l}\text { Penduduk agama kristen }=\text { Fraksi penduduk } \\
\text { agama kristen*Jumlah penduduk }\end{array}$ & $\begin{array}{l}\text { Orang/ } \\
\text { year }\end{array}$ \\
\hline 29. & $\begin{array}{l}\text { Kebutuhan hari } \\
\text { raya natal }\end{array}$ & Variabel & $\begin{array}{l}\text { Kebutuhan hari raya natal = Jumlah KK } \\
\text { agama katolik*Kebutuhan per KK agama } \\
\text { katolik }\end{array}$ & $\begin{array}{l}\text { Ton/ } \\
\text { year }\end{array}$ \\
\hline 30. & $\begin{array}{l}\text { Jumlah KK agama } \\
\text { katolik }\end{array}$ & Variabel & $\begin{array}{l}\text { Jumlah KK agama katolik = Penduduk } \\
\text { agama katolik/Rata rata anggota keluarga } \\
\text { agama katolik }\end{array}$ & $\begin{array}{l}\text { KK/ } \\
\text { year }\end{array}$ \\
\hline 31. & $\begin{array}{l}\text { Penduduk agama } \\
\text { katolik }\end{array}$ & Variabel & $\begin{array}{l}\text { Penduduk agama katolik = Fraksi penduduk } \\
\text { agama katolik*Jumlah penduduk }\end{array}$ & $\begin{array}{l}\text { Orang/ } \\
\text { year }\end{array}$ \\
\hline
\end{tabular}




\begin{tabular}{|c|c|c|c|c|}
\hline No. & $\begin{array}{l}\text { Variabel di causal } \\
\text { loop }\end{array}$ & $\begin{array}{l}\text { Model } \\
\text { Building }\end{array}$ & Formulasi & Unit \\
\hline 32. & $\begin{array}{l}\text { Kebutuhan hari } \\
\text { raya imlek }\end{array}$ & Variabel & $\begin{array}{l}\text { Kebutuhan hari raya imlek = Jumlah KK } \\
\text { agama budha*Kebutuhan per KK agama } \\
\text { budha }\end{array}$ & $\begin{array}{l}\text { Ton/ } \\
\text { year }\end{array}$ \\
\hline 33. & $\begin{array}{l}\text { Jumlah KK agama } \\
\text { budha }\end{array}$ & Variabel & $\begin{array}{l}\text { Jumlah KK agama budha = Penduduk } \\
\text { agama budha/Rata rata anggota keluarga } \\
\text { agama budha }\end{array}$ & $\begin{array}{l}\text { Ton/ } \\
\text { year }\end{array}$ \\
\hline 34. & $\begin{array}{l}\text { Penduduk agama } \\
\text { budha }\end{array}$ & Variabel & $\begin{array}{l}\text { Penduduk agama budha = Fraksi penduduk } \\
\text { agama budha*Jumlah penduduk }\end{array}$ & $\begin{array}{l}\text { Orang/ } \\
\text { year }\end{array}$ \\
\hline 35. & $\begin{array}{l}\text { Kebutuhan hari } \\
\text { raya imlek }\end{array}$ & Variabel & $\begin{array}{l}\text { Kebutuhan hari raya imlek = Jumlah KK } \\
\text { agama kong hu chu *Kebutuhan per KK } \\
\text { agama kong hu chu }\end{array}$ & $\begin{array}{l}\text { Ton/ } \\
\text { year }\end{array}$ \\
\hline 36. & $\begin{array}{l}\text { Jumlah KK agama } \\
\text { kong hu chu }\end{array}$ & Variabel & $\begin{array}{l}\text { Jumlah KK agama kong hu chu = Penduduk } \\
\text { agama kong hu chu /Rata rata anggota } \\
\text { keluarga agama kong hu chu }\end{array}$ & $\begin{array}{l}\text { Ton/ } \\
\text { year }\end{array}$ \\
\hline 37. & $\begin{array}{l}\text { Penduduk agama } \\
\text { kong hu chu }\end{array}$ & Variabel & $\begin{array}{l}\text { Penduduk agama kong hu chu = Fraksi } \\
\text { penduduk agama kong hu chu *Jumlah } \\
\text { penduduk }\end{array}$ & $\begin{array}{l}\text { Orang/ } \\
\text { year }\end{array}$ \\
\hline 38. & $\begin{array}{l}\text { Kebutuhan per KK } \\
\text { agama kong hu chu }\end{array}$ & Variabel & $\begin{array}{l}\text { Kebutuhan per KK agama kong hu chu = } \\
\text { Rata rata kebutuhan per KK penduduk } \\
\text { beragama kong hu chu }\end{array}$ & $\begin{array}{l}\text { Ton/ } \\
\text { year }\end{array}$ \\
\hline 39. & Kebutuhan industri & Variabel & $\begin{array}{l}\text { Kebutuhan industri sosis ayam+Kebutuhan } \\
\text { industri bakso ayam+Kebutuhan industri } \\
\text { ayam goreng }\end{array}$ & $\begin{array}{l}\text { Ton/ } \\
\text { year }\end{array}$ \\
\hline 40. & $\begin{array}{l}\text { Kebutuhan industri } \\
\text { sosis ayam }\end{array}$ & Variabel & $\begin{array}{l}\text { Jumlah industri sosis ayam*Rata rata } \\
\text { kapasitas produksi industri sosis ayam }\end{array}$ & $\begin{array}{l}\text { Ton/ } \\
\text { year }\end{array}$ \\
\hline 41. & $\begin{array}{l}\text { Kebutuhan industri } \\
\text { bakso ayam }\end{array}$ & Variabel & $\begin{array}{l}\text { Jumlah industri bakso ayam*Rata rata } \\
\text { kapasitas produksi industri bakso ayam }\end{array}$ & $\begin{array}{l}\text { Ton/ } \\
\text { year }\end{array}$ \\
\hline 42. & $\begin{array}{l}\text { Kebutuhan industri } \\
\text { ayam goreng }\end{array}$ & Variabel & $\begin{array}{l}\text { Fraksi kebutuhan industri ayam } \\
\text { goreng*Jumlah penduduk }\end{array}$ & $\begin{array}{l}\text { Ton/ } \\
\text { year }\end{array}$ \\
\hline 43. & $\begin{array}{l}\text { Ketersediaan } \\
\text { daging ayam ras } \\
\text { pedaging }\end{array}$ & Stock & $\begin{array}{l}\text { Produksi daging ayam ras pedaging- } \\
\text { Kebutuhan daging ayam ras pedaging }\end{array}$ & Ton \\
\hline
\end{tabular}

